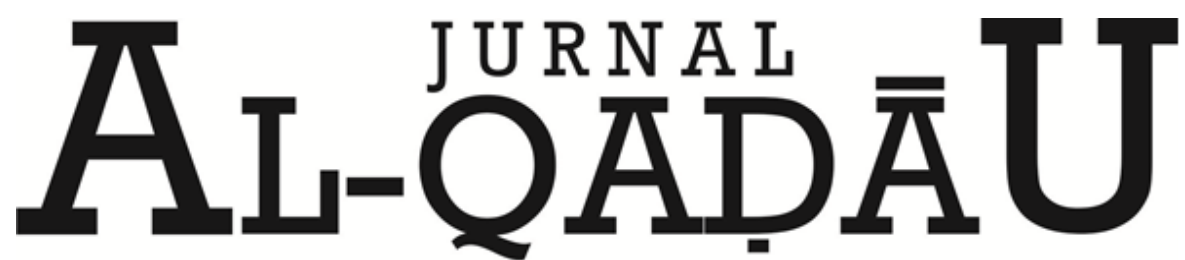 \\ PERADILAN dan HUKUM KELUARGA ISLAM
}

\section{Posisi Hukum Islam dalam Hukum Nasional di Indonesia}

\section{Islamic Law Existence In National Law Of Indonesia}

Ajub Ishak

Dosen IAIN Sultan Amai Gorontalo

Email : ajubisha@gmail.com

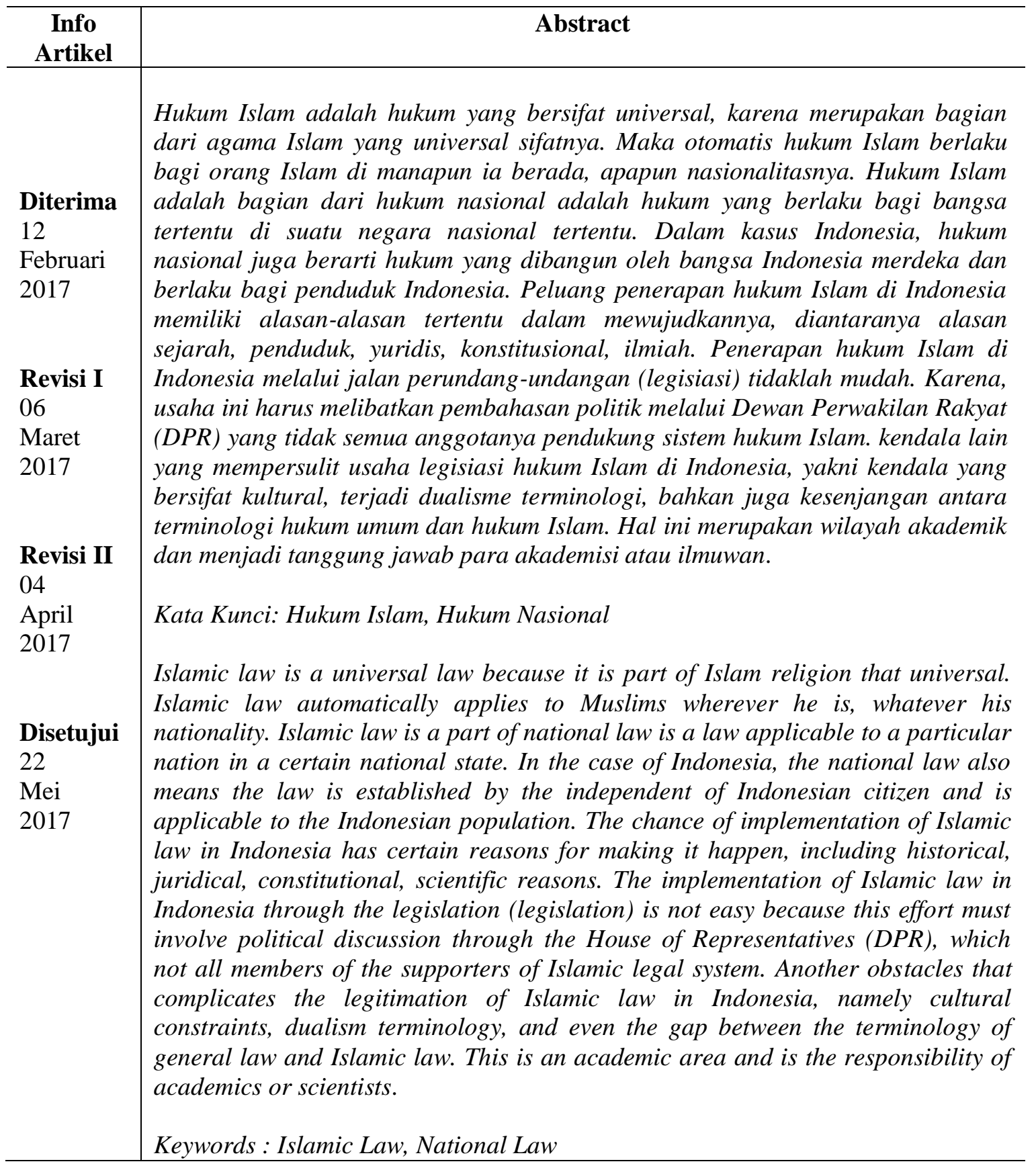


Ajub Ishak

\section{PENDAHULUAN}

Dalam kehidupan manusia, agama menjadi seperangkat pedoman hidup, yakni satu-satunya pedoman yang dapat menjelaskan keberadaan manusia kini, asal- usulnya, dan masa depannya setelah mati. Tidak ada pedoman lain dalam kebudayaan manusia yang mampu memberikan penjelasan tentang eksistensi manusia selengkap yang dilakukan agama. ${ }^{1}$ Agama dan manusia tidak dapat dipisahkan, karena jika manusia tidak beragama maka akan kehilangan pedoman dalam mengontrol kehidupannya. Dan bagi umat Islam memiliki seperangkat hokum yang dikenal dengan hukum Islam, yang dinilai mampu menyelesaikan permasalahan yang dihadapi manusia di era globaisasi.

Hukum Islam dan era globalisasi sering dipersepsikan ke dalam dua hal yang sangat berbeda dan bahkan dikatakan saling bertentangan. Dalam salah satu sudut pandang, hukum Islam merupakan sesuatu yang tidak mungkin mengalami perubahan, karena berdasarkan wahyu Allah yang bersifat qadim. Setiap yang qadim, adalah sesuatu yang bersifat statis tidak berubah. Sebaliknya, era globalisasi secara substansial mengalami perubahan cukup besar dan bersifat dinamis. Sesuatu yang bersifat dinamis tidak mungkin dihubungkan kepada yang bersifat stabil dan statis ${ }^{2}$

Hukum Islam dalam aturan tertentu seperti aturan tentang ibadah tentunya tidak mungkin mengalami perubahan, tetapi dalam lingkup sosial kemasyarakatan tentunya dapat berubah sesuai dengan perubahan waktu dan perkembangan zaman. Hal ini menjadi dasar diberlakukannya sebuah aturan dengan memperhatikan perubahan sosial yang terjadi di masyarakat, yang membutuhkan alat kontrol. Menurut Badri Khaeruman, perubahan sosial akan berjalan pincang jika tidak ada alat kontrol sebagai pengawal moral dan landasan etika dalam proses interaksi sosial. ${ }^{3}$ Alat kontrol yang mengikat sangat penting bagi kehidupan sosial masyarakat yang merupakan sebuah komunitas yang berbeda dalam memahami ajaran agamanya.

Komunitas Islam terbelah menjadi dua friksi, pertama berpendapat bahwa Islam merupakan ideologi sempuma. Mulai dari hal-hal terkecil dalam kehidupan ini, sampai

\footnotetext{
${ }^{1}$ Abdul Halim, Politik Hukum Islam Di Indonesia (Cet I; Ciputat, Ciputat Press, 2005), h. 7

${ }^{2}$ Amir Syarifuddin, Meretas Kebekuan Ijtihad: ISU-ISU Penting hokum Islam Kontemporer di Indonesia (Cet. II: Ciputat: ; Ciputat Press, 2005), h. 3

${ }^{3}$ Badri Khaeruman, Hukum Islam dalam Perubahan Sosial (Cet. I; Bandung: Pustaka Setia, 2010), h. 37
} 
pada soal mengurus negara. Tidak ada dikotomi antara negara dan agama. Semua itu menjadi satu dan terilustrasikan dalam kehidupan seorang muslim. Sedangkan yang kedua adalah mereka yang selama ini menamakan dirinya sebagai komunitas Islam inklusiv, kerap mengusung tema kemanusiaan, pluralisme, dan segenap istilah lain yang pro Barat. ${ }^{4}$ Hal ini yang memerlukan kajian yang mendalam dari sudut pandang hukum Islam yang diterapkan kepada masyarakat Indonesia yang dominan umat Islam.

Sejarah umat Islam di Indonesia pada hakikatnya adalah sosok dari bangsa, karena jumlah umat Islam yang mayoritas dan dominan, seharusnya mampu menentukan pola berpikir dan pola pembentukan hukum bangsa Indonesia. Islam sebagai salah satu agama di Indonesia telah meletakkan pelataran nasionalisme guna menentang penjajah yang akhimya menghasilkan kemerdekaan Indonesia. ${ }^{5}$ Hukum Islam yang telah diberlakukan negara sebagai hukum positif dilingkungan peradilan, masih sangat terbatas; yaitu hukum perkawinan, kewarisan dan wakaf atau dalam arti sebagian dari hukum perdata. Sedangkan sebagian besar, diantaranya; bidang muamalat, jinayat, hukum acara dan hukum negara, seperti masih dalam bentuknya sebagai fikih atau pedoman dalam beramal. ${ }^{6}$

Dapatkah bidang lain itu menjadi hukum positif yang mengikat terhadap seluruh warga negara (termasuk yang non muslim). Hal ini masih menghadapi rintangan bahkan tantangan yang harus dihadapi, terutama dalam hal kesadaran umat Islam sendiri untuk mematuhi agamanya. Tidak semua umat Islam yang telah menjalankan ibadah Islam mempunyai kesadaran menjalankan semua ajaran Islam. Kalau umat Islam banyak yang belum berkenan menjalankan ajaran agamanya (hukum Islam), bagaimana mengharapkan warga negara non muslim bersedia menerima penerapan hukum Islam tersebut. Oleh karena itu akan dikemukakan permasalahan yakni bagaimana posisi hukum Islam dalam hukum nasional serta bagaimana peluang dan tantangan penerapan hokum Islam di Indonesia

\footnotetext{
${ }^{4}$ Mahmud Al-Anshari, Penegakan Syari'at Islam: Dilema Keumatan di Indonesia (Cet. I; Jakarta: Inisiasi Press, 2005), h. 43.

${ }^{5}$ Mohd. Idris Ranumulyo, Asas-asas Hukum Islam: Timbul dan Kedudukan Hukum Islam dalam Sistem Hukum di Indonesia (Cet. 2; Sinar Grafika, 1997), h. 117

${ }^{6}$ Amir Syarifuddin, Meretas Kebekuan Ijtihad: ISU-ISU Penting hukum Islam Kontemporer di Indonesia, h. 40.
} 
Ajub Ishak

\section{PEMBAHASAN}

\section{A. Hukum Islam dalam Hukum Nasional}

Hukum Islam yang mengatur hubungan manusia secara vertikal dengan Allah swt., maupun yang mengatur hubungannya dengan sesama manusia, mempunyai peranan dalam pembentukan hukum nasional. Hal ini didasarkan pada kenyataan bahwa banyak aturan-aturan dan ketentuan-ketentuannya, yang selama ini dikenal dalam hukum Islam telah terserap ke dalam hukum perundang-undangan negara. ${ }^{7}$ Peranan hukum Islam dalam pembentukan hukum nasional dapat dilihat dari dua sisi, yaitu dari sisi hukum Islam sebagai salah satu sumber pembentukan hukum nasional, dan dari sisi diangkatnya hukum Islam sebagai hukum negara.

GBHN telah menetapkan bahwa hukum nasional harus dijiwai dan didasari oleh Pancasila dan UUD 1945, karena Pancasila ditetapkan sebagai sumber dari segala sumber hukum dan menjadi landasan semua produk hukum di Indonesia. Sila pertama dari Pancasila adalah Ketuhanan Yang Maha Esa dan pasal 29 UUD menetapkan bahwa negara berdasarkan Ketuhanan yang Maha Esa. Kedua hal ini menuntut agar hukum nasional itu berlandaskan Ketuhanan Yang Maha Esa. Bagi bangsa Indonesia pengertian berlandaskan Ketuhanan Yang Maha Esa itu mengandung arti "berdasarkan agama", karena mayoritas bangsa Indonesia adalah beragama dan hanya bagian yang sangat kecil dari yang percaya kepada Tuhan Yang Maha Esa itu yang tidak beragama. $^{8}$

Dengan demikian, pembentukan hukum nasional mengambil dan bersumber pada hukum yang hidup dalam masyarakat, maka dengan sendirinya hukum Islam berperan dalam pembentukan hukum nasional. Hal ini merupakan realisasi dari tuntutan dijadikannya hukum Islam menjadi salah satu bahan rujukan dan sumber dari pembentukan hukum nasional, fakta menunjukkan sudah begitu banyak unsur- unsur hukum Islam masuk dalam produk legislatif terutama sejak masa orde baru.

Hukum Islam memasuki produk hukum nasional bukan hanya yang berkaitan ibadah, hukum keluarga atau perkawinan, dan hukum tentang tanah wakaf. Adanya

\footnotetext{
${ }^{7}$ Amir Syarifuddin, Meretas Kebekuan Ijtihad: ISU-ISU Penting hukum Islam Kontemporer di Indonesia, h. 20.

${ }^{8}$ Amir Syarifuddin, Meretas Kebekuan Ijtihad: ISU-ISU Penting hukum Islam Kontemporer di Indonesia, h.30. Cik Hasan Bisri (Penyunting), Kompilasi Hukum Islam dan Peradilan Agama dalam Sistem Hukum Nasional (Cet. II; Jakarta: Logos Wacana llmu, 1999), h. 3.
} 
sistem bagi hasil (mudarabah) dalam Undang-Undang perbankan, adanya makanan halal dalam Undang-undang Pangan, menunjukkan telah masuknya fikih (hukum Islam) dalam poduk hukum nasional.

Dalam pembentukan hukum nasional terdapat hal-hal yang perlu dicermati, yaitu: ${ }^{9}$

Diterimanya hukum Islam masuk ke dalam hukum nasional bukan hanya karena hukum Islam diikuti mayoritas masyarakat bangsa Indonesia, tetapi karena hukum Islam memang mampu memenuhi tuntutan keadilan. Dengan masuknya hukum Islam ke dalam hukum nasional, ia tidak lagi akan menggunakan label Islam dan juga tidak lagi menjadi milik umat Islam saja, tetapi menjadi milik bangsa.

Pakar hukum Islam harus mampu menggali nilai-nilai universal dari hukum Islam untuk disumbangkan menjadi hukum nasional, supaya tidak akan menghadapi kendala penolakan dari anggota badan legislatif yang tidak beragama Islam.

Hukum Islam sangat identik dengan keadilan dan mampu memenuhi tuntutan keadilan, dan dalam pelaksanannya memiliki tempat di kalangan masyarakat dalam arti dapat diterima oleh semua masyarakat termasuk non muslim, karena sudah menjadi milik negara. Oleh arena itu, keuniversalan hukum Islam membutuhkan kajian yang lebih komprehensif, agar dapat terkomodir dalam perumusan peraturan perundangundangan yang disusun dan oleh anggota badan legislatif.

\section{B. Penerapan Hukum Islam Di Indonesia}

Indonesia adalah negara hukum, ${ }^{10}$ hal ini menjadi titik tolak dari berbagai pembentukan aturan yang bersifat mengikat bagi masyarakat di Indonesia. Segala macam aturan yang dibentuk dan ditetapkan tentunya objeknya adalah masyarakat sebagai warga negara. Karena hukum adalah segala aturan yang sifatnya memaksa dan mengikat setiap warga negara, dan yang melanggamya mendapatkan hukuman atau sanksi. ${ }^{11}$ Sejalan dengan pemyataan ini, maka posisi hukum Islam di Indonesia sangat

${ }^{9}$ Amir Syarifiiddin, Meretas Kebekuan Ijtihad: ISU-ISU Penting hokum Islam Kontemporer di Indonesia, h. 34.

${ }^{10}$ Intinya, bahwa Indonesia, seperti Negara berkembang lainnya, selalu berusaha menjalankan pembangunan hukum nasional, yang dalam prakteknya sarat dengan nuansa dan pengaruh politik penguasa Lihat A. Qodri Azizy, Eklekiisisme Hukum Nasional; Kompetisi antara Hukum Islam dan Hukum Umum (Cet. I; Yogyakarta: Gama Media, 2002), h. 174.

${ }^{11}$ Ajub Ishak, "Pembentukan Hukum dan Tingkah Laku Sosial," Al-Mizan:Jurnal Pemikiran Hukum dan Ekonomi Islam 6, no 1 (Juni 2010): h. 1. 
Ajub Ishak

strategis dalam rangka penerapannya di Indonesia, karena keuniversalan hukum Islam, dan dominannya umat Islam di Indonesia.

Islam diyakini sebagai agama yang universal, tidak terbatas oleh ruang dan waktu. Oleh karena itu, Islam seharusnya dapat diterima oleh setiap manusia, tanpa harus ada pertentangan dengan situasi dan kondisi di mana manusia itu berada. Islam dapat berhadapan dengan masyarakat modern, sebagaimana ia dapat berhadapan dengan masyarakat yang bersahaja. Ketika berhadapan dengan masyarakat modern dengan tantangan modernitasnya, Islam dituntut dapat menghadapi tantangan modernitas. ${ }^{12}$

Hukum Islam adalah hukum yang bersifat universal, karena merupakan bagian dari agama Islam yang universal sifatnya. Maka otomatis hukum Islam berlaku bagi orang Islam di manapun ia berada, apapun nasionalitasnya. Hukum Islam adalah bagian dari hukum nasional adalah hukum yang berlaku bagi bangsa tertentu di suatu negara nasional tertentu. Dalam kasus Indonesia, hukum nasional juga berarti hukum yang dibangun oleh bangsa Indonesia merdeka dan berlaku bagi penduduk Indonesia.

Indonesia merupakan negara yang memiliki masyarakat muslim lebih banyak dibandingkan dengan masyarakat yang beragama lain. Masyarakat yang lebih banyak tersebut berperan lebih besar dalam menjalankan ajaran agamanya khususnya dalam menerapkan hukum Islam. Dalam menerapkan hukum Islam tersebut membutuhkan kajian yang komprehensif dan menyeluruh dengan mempertimbangkan eksistensi masyarakat yang akan melaksanakan aturan/hukum tersebut, yang bukan hanya masyarakat muslim tetapi juga masyarakat umat lain (non muslim) yang ada di Indonesia.

Kajian keberadaan hukum Islam dalam konteks ini dimaksudkan untuk mengenal dan menganalisis hukum Islam dalam konteks budaya hukum Indonesia sebagai sesuatu yang hidup dan berkembang secara dinamis. Setiap masyarakat memiliki ciri khas dan karakter-karakter sendiri, termasuk budaya hukum. ${ }^{13}$ Budaya hukum tersebut berasal dari berbagai sumber, antara lain norma-norma sosial kemasyarakatan yang dipegang teguh dan diyakini mampu mengatur lingkungan sosial

\footnotetext{
${ }^{12}$ Amir Mu'allim dan Yusdani, Konfigurasi Pemikiran Hukum Islam (Cet. 1; Yogyakarta: UII Press, 1999), h. 1.

${ }^{13}$ Abdul Halim, Politik Hukum Islam Di Indonesia, h. 35 
kemasyarakatan. Dalam konteks keindonesiaan, maka hukum Islam diyakini sebagian besar umat Islam Indonesia sebagai sesuatu norma hukum yang benar mempunyai peran dominan dalam mengatur budaya hukum tersebut.

Pelaksanaan hukum Islam kaitannya dengan sistem hukum positif di Indonesia, atau antara hukum Islam dan negara sudah banyak ditulis oleh para sarjana, termasuk sarjana barat. Membicarakan tentang kekuatan hukum dari hukum Islam di Indonesia perlu dipahami dari macam produk pemikiran hukum Islam. Bahwa setidaknya ada empat produk pemikiran hukum Islam yang telah berkembang dan berlaku di Indonesia, seiring pertumbuhan dan perkembangannya. Empat produk pemikiran hukum Islam tersebut adalah fikhi, fatwa ulama- hakim, keputusan pengadilan, dan perundang-undangan. ${ }^{14}$ Produk pemikiran ini khususnya di Indonesia telah berlaku dan sudah dilaksanakan oleh masyarakat Indonesia, dengan diundangkannya perarturan perundang-undangan, fatwa ulama, dan putusan hakim yang memiliki kekuatan hukum. Tetapi hal ini masih membutuhkan langkah-langkah yang strategis dalam rangka penguatan upaya penerapan hukum Islam di Indonesia.

Penerapan hukum Islam membutuhkan langkah-langkah sebagai alat penekan dan pemaksa, yakni dengan meningkatkan kesadaran umat Islam, tentang tuntutan ajaran agamanya secara menyeluruh, kemudian berupaya meyakinkan umat beragama lain tentang kemampuan hukum Islam (dalam formulasinya yang baru) sebagai hukum negara. ${ }^{15}$

Akhir-akhir ini, tingkat kesadaran dalam beragama di kalangan umat Islam semakin baik. Sebelumnya memang dirasakan adanya usaha pihak tertentu untuk meminggirkan umat Islam dalam melaksanakan ajaran agamanya, namun saat ini usaha untuk menyudutkan umat Islam tersebut dapat dihindarkan, meskipun belum seluruhnya. Hal ini merupakan kesempatan untuk menyiapkan masuknya hukum Islam dalam hukum yang diberlakukan di Indonesia.

D. Peluang dan Tantangan Penerapan Hukum Islam Di Indonesia

\footnotetext{
${ }^{14}$ Ahmad Rofiq, Hukum Islam Di Indonesia (Cet 4; Jakarta: Raja Grafindo Persada, 2000), h. 24-25. Ahmad Rofiq, Pembaharuan Hukum Islam di Indonesia (Cet. 1; Yogyakarta: Gama Media, 2001), h. $30-32$.

${ }^{15}$ Amir Syarifuddin, Meretas Kebekuan Ijtihad: ISU-ISU Penting hukum Islam Kontemporer di Indonesia, h. 40.
} 
Ajub Ishak

Salah satu fungsi hukum Islam (syariat Islam) adalah sebagai nilai-nilai normatif, yang dapat memberikan legitimasi terhadap perubahan-perubahan yang dikehendaki dalam penyelarasan antara ajaran Islam dan dinamika sosial. Dengan demikian, hukum Islam berfungsi ganda. Sebagai hukum, ia berusaha mengatur tingkah laku manusia (umat Islam) sesuai dengan citra Islam, dan sebagai norma ia memberikan legitimasi ataupun larangan-larangan tertentu dalam konteks spiritual. ${ }^{16}$ Syariat Islam adalah bagian dari agama, dan agama bagi umat Islam mengandung dua sisi; pertama adalah apa yang harus diyakininya, ketentuan tentang apa yang harus diyakininya disebut akidah, dan kedua apa yang harus diamalkannya, petunjuk tentang apa yang harus diamalkannya disebut syariat. ${ }^{17}$ Pengamalan kedua sisi tersebut harus diimplementasikan dalam kehidupan bermasyarakat dan individu.

Bila seseorang telah meyakini Islam sebagai agamanya tanpa ada paksaan, maka dengan sendirinya ia harus menjalankan akidah dan sekaligus menjalankan syariah. Tidak ada cara Iain yang harus diikutinya kecuali dua hal tersebut. Bila Seseorang tidak bersedia menjalankan akidah islam, berarti ia dengan sendirinya sudah menarik dirinya dar ajaran agama Islam. Demikian pula bila seorang muslim sudah keberatan menjalankan syariat Islam berarti ia tidak bersedia lagi menganut agama Islam. ${ }^{18}$ Hal ini membutuhkan perhatian maksimal, karena umat Islam berkewajiban menjalankan agamanya termasuk aturan hukumnya secara baik dan benar berdasarkan tuntutan al-Qur'an dan sunnah.

Bagi umat Islam menjalankan hukum Islam atau syariat adalah bagian dari menjalankan agama dan tidak memerlukan tekanan dari luar dalam bentuk apapun. Syariat Islam merupakan pedoman dalam beramal, baik dalm hubungannya dengan Allah, maupun dalam pergaulannya dengan hamba Allah atau sesame manusia. Sejauh yang menyangkut hubungannya dengan sesame manusia, maka amalannya dipertanggungjawabkan kepada Allah dan kepada manusia yang berhubungan dengannya. Selama peraturan Allah tentang pergaulan sesama manusia telah

\footnotetext{
${ }^{16}$ Sudirman Tebba, Sosiologi Hukum Islam (Cet. I; Yogyakarta: UII Press, 2003), h. 1-2

${ }^{17}$ Amir Syarifuddin, Meretas Kebekuan Ijtihad: ISU-ISU Penting hukum Islam Kontemporer di Indonesia, h. 36.

${ }^{18}$ Amir Syarifuddin, Meretas Kebekuan Ijtihad: ISU-ISU Penting hukum Islam Kontemporer di Indonesia.
} 
dipatuhinya dengan baik, tidak ada tuntutan dari Allah atau dari manusia yang berhubungan dengannya. Tetapi kalau aturan Allah tentang pergaulan tidak dijalankannya dengan baik, ia akan dituntut Allah karena melalaikan pedoman yang telah diterapkan Allah, dan ia akan berhadapan dengan umat tempat ia bersosialisasi. ${ }^{19}$

Meskipun hukum Islam merupakan bagian dari agama yang harus dijalankan oleh umat Islam, namun dalam penerapannya kelihatannya belum sepenuhnya berlaku terutama dalam hal yang berhubungan dengan pergaulan sesame manusia (muamlat dalam arti umum yang mencakup privat dan publik).

Hal ini mungkin disebabkan oleh umat Islam sendiri yang belum siap untuk menerapkannya meskipun itu perintah Allah, karena fikih bidang muamalat menurut apa adanya yang tercantum dalam kitab-kitab fikih sulit untuk diterapkan dalam kenyataan. Kecuali telah diformulasikan dalam bentuk yang barn sebagaimana dalam hukum perkawinan. Meskipun fikih munakahat telah diformulasikan dalam UndangUndang Perkawinan, namun dalam pelaksanaannya masih menemukan kesulitan. Karena sebagian umat Islam sendiri belum berkenan menempatkannya sebagai pedoman dalam beramal karena ia bukan fikih. ${ }^{20}$ Hal ini membutuhkan kajian yang lebih komprehensif tentang peluang penerapan hukum Islam di Indonesia, sekaligus tantangan yang dihadapi dalam pelaksanaan hukum Islam di Indonesia, terutama bagi kalangan umat Islam sendiri.

\section{Peluang Penerapan Hukum Islam di Indonesia}

Penerapan hukum Islam di Indonesia memiliki peluang yang cukup besar, antara lain dengan jumlah masyarakat Islam di Indonesia dengan jumlah yang banyak. Pembicaraan tentang hukum Islam dalam tradisi masyarakat pemeluknya, tidak hanya sampai pada kesimpulan bahwa Islam hanya akan didefmisikan dengan apa yang menjadi praktek masyarakatnya, seperti yang tetjadi bagi ahli antropologi. Namun, akan sampai pada kesimpulan bahwa nilai-nilai hukum Islam dari norma sampai

\footnotetext{
${ }^{19}$ Amir Syarifuddin, Meretas Kebekuan Ijtihad: ISU-ISU Penting hukum Islam Kontemporer di Indonesia, h. 37

${ }^{20}$ Amir Syarifuddin, Meretas Kebekuan Ijtihad: ISU-ISU Penting hukum Islam Kontemporer di Indonesia, h. 39.
} 
Ajub Ishak

dengan aturan (rules), tidak boleh diabaikan dari keberadaan masyarakat pemeluknya. ${ }^{21}$ Hukum Islam sebagai norma wajib ditegakkan khususnya oleh pemeluknya, karena ia adalah aturan yang diyakini dapat dilaksanakan dan diterapkan, serta merupakan peluang yang harus diraih oleh umat Islam. Peluang penerapan hukum Islam di Indonesia memiliki alasan-alasan tertentu dalam mewujudkannya, alasan tersebut adalah: ${ }^{22}$

\section{a. Alasan Sejarah}

Hukum Islam baru dikenal setelah Islam disebarkan di Indonesia, dan dapat dikatakan bahwa setelah Islam datang ke Indonesia, hukum Islam telah diikuti dan dilaksanakan oleh pemeluk agama Islam di Nusantara ini. Hal itu dapat dilihat pada studi para pujangga yang hidup pada masa itu mengenai hukum Islam dan peranannya dalam menyelesaikan perkara-perkara yang timbul dalam masyarakat. ${ }^{23}$ Tinjauan sejarah ini menjadi bukti bahwa berlakunya hukum Islam seiring dengan masuknya Islam ke Indonesia

b. Alasan Penduduk

Menurut sensus, hampir Sembilan puluh persen (tepatnya 88,09\% menurut sensus 1980), penduduk Indonesia mengaku beragama Islam. Ini berarti bahwa mayoritas manusia yang mendiami kepulauan Nusantara adalah pemeluk agama Islam. Karena penduduk Indonesia mayoritas beragama Islam, maka sejak dahulu, para pegawai, pejabat pemerintahan dan atau para pimpinan yang akan bekeija di Indonesia selalu dibekaii dengan pengetahuan keislaman, baik tentang lembaganya maupun tentang hukumnya yang tumbuh dan berkembang di masyarakat Muslim Indonesia.

\section{c. Alasan Yuridis}

Di Indonesia, hukum Islam berlaku secara normatif dan yuridis formal. Yang berlaku secara normatif adalah hukum Islam mempunyai sanksi

\footnotetext{
${ }^{21}$ A. Qodri Azizy, Eklekiisisme Hukum Nasional; Kompetisi antara Hukum Islam dan Hukum Umum, h. 184.

${ }^{22}$ Mohammad Daud Ali, Hukum Islam: Pengantar Ilmu Hukum dan Tata Hukum Islam di Indonesia (Jakarta: Raja Grafindo Persada, 2007), h. 4-10

${ }^{23}$ Mohammad Daud Ali, Hukum Islam: Pengantar Ilmu Hukum dan Tata Hukum Islam di Indonesia, h. 209. Mustofa dan Abdul Wahid, Hukum Islam Kontemporer(Cet. 1; Jakarta: Sinar Grafika, 2009), h. 114-124
} 
kemasyarakatan apabila norma-normanya dilanggar. Hukum Islam yang berlaku secara normatif di Indonesia diantaranya adalah pelaksanaan ibadah. Dan yang berlaku secara yuridis formal adalah hukum Islam yang mengatur hubungan manusia dengan manusia lain dan benda dalam masyarakat. Bagian hukum Islam ini menjadi hukum positif berdasarkan peraturan perundang-undangan yang telah diberlakukan.

\section{d. Alasan Konstitusional}

Di bawah Bab Agama, dalam Pasal 29 ayat (1) Undang-Undang Dasar 1945 dinyatakan bahwa Negara (Republik Indonesia) berdasarkan atas Ketuhanan Yang Maha Esa. ${ }^{24}$

\section{e. Alasan Ilmiah}

Sebagai bidang ilmu, hukum Islam telah lama dipelajari secara ilmiah, bukan saja oleh orang Islam sendiri tetapi juga oleh orang-orang non-muslim. Orang Barat non-Muslim ini, yang biasa disebut dengan istilah orientalis, mempelajari hukum Islam dengan berbagai tujuan yang berubah-ubah. Sejarah telah menatat, bahwa hukum Islam sebagai bidang ilmu dipelajari di perguruan tinggi umum, bahkan sampai sekarang kaiangan perguruan tinggi umum tersebut, banyak menghasilkan kajian ilmiah atau penelitian tentang hukum Islam.

\section{Tantangan Penerapan Hukum Islam di Indonesia}

Penerapan hukum Islam di Indonesia melalui jalan perundang-undangan (legisiasi) tidaklah mudah. Karena, usaha ini harus melibatkan pembahasan politik melalui Dewan Perwakilan Rakyat (DPR) yang tidak semua anggotanya pendukung sistem hukum Islam. Disamping itu, terdapat kendala lain yang mempersulit usaha legisiasi hukum Islam di Indonesia, yakni kendala yang bersifat kultural. ${ }^{25}$ Kendala dan kesulitan yang dihadapi dalam menerapkan hukum Islam di Indonesia, tentunya harus diminimaiisir, termasuk kemungkinan-kemungkinan yang muncul dalam upaya penerapan hukum Islam di Indonesia.

\footnotetext{
${ }^{24}$ Suparman Usman, Hukum Islam: Asas- asas dan Pengantar Studi Tata Hukum Indonesia (Get. 2; Jakarta; Gama Media Pratama, 2002), h. 122-127

${ }^{25}$ Mustofa dan Abdul Wahid, Hukum Islam Kontemporer, h. 137-138.
} 
Ajub Ishak

Terdapat beberapa kemungkinan yang berkaitan dengan kajian hukum Islam, yaitu: 26

Para ahli hukum enggan atau bahkan takut untuk mengkaji Islam yang berkaitan dengan hukum atau dengan istilah baku "hukum Islam", karena "Islam phobia" penguasa selama beberapa dekade. Keengganan ini juga mungkin disebabkan oleh kenyataan bahwa banyak ahli hukum Indonesia yang sangat taat menjadi pengikut setia ilmu hukum Belanda.

Kondisi masyarakat Indonesia sekarang masih dirasa belum begitu mendesak para ahli hukum untuk sekaligus mendalami atau setidaknya memahami hukum Islam, ketika mengkaji hukum pada umumnya. Belum ada langkah kebijakan nasional mengenai perlunya kajian hukum Islam Indonesia. Para politisi belum menjadikan hukum Islam sebagai diskursus yang dominan dalam mengadakan reformasi hukum (di Indonesia pada khususnya, dan dalam memperbaiki sistem sosial politik di Indonesia pada umumnya. Masih terjadi dualisme terminologi, bahkan juga kesenjangan antara terminologi hukum umum dan hukum Islam. Hal ini merupakan wilayah akademik dan menjadi tanggung jawab para akademisi atau ilmuwan, baik akademisi ilmu hukum umum maupun ilmu hukum Islam.

\section{PENUTUP}

\section{A. Kesimpulan}

1. Pembentukan hukum nasional mengambil dan bersumber pada hukum yang hidup dalam masyarakat, maka dengan sendirinya hukum Islam berperan dalam pembentukan hukum nasional. Hal ini merupakan realisasi dan tuntutan dijadikannya hukum Islam menjadi salah satu bahan rujukan dan sumber dari pembentukan hukum nasional, karena sudah banyak unsur-unsur hukum Islam memasuki produk legislatif terutama sejak masa orde baru. Hukum Islam memasuki produk hukum nasional bukan hanya yang berkaitan dengan hukum keluarga atau perkawinan, dan hukum tentang tanah wakaf, tetapi mencakup aturan perundang-undangan lainnya. Adanya sistem bagi hasil (mudarabah) dalam Undang-Undang perbankan, adanya makanan halal dalam Undang-

${ }^{26}$ A. Qodri Azizy, Eklektisisme Hukum Nasional: Kompetisi Antara Hukum Islam dan Hukum Umum., h. 179-181. 
undang Pangan, perlindungan anak dan kekerasan dalam rumah tangga, menunjukkan telah masuknya hukum Islam dalam produk hukum nasional.

2. Penerapan hukum Islam di Indonesia memiliki peluang yang cukup besar, antara lain dengan jumlah masyarakat Islam di Indonesia dengan jumtah yang banyak. Pembicaraan tentang hukum Islam dalam tradisi masyarakat pemeluknya, tidak hanya sampai pada kesimpulan bahwa Islam hanya akan didefinisikan dengan apa yang menjadi praktek masyarakatnya. Peluang tersebut dikatakan besar karena alasan sejarah, jumlah penduduk, yuridis, konstitusional dan ilmiah. Sedangkan kemungkinan tantangan dalam penerapan hukum Islam di Indonesia, yaitu; keengganan para ahli hukum dalam mengkaji kebijakan nasional dan terjadinya dualisme terminologi tentang hukum Islam.

\section{B. Implikasi}

1. Perlunya upaya yang maksimal dalam mengkaji hukum Islam di kalangan perguruan tinggi khususnya perguruan tinggi Islam, yang memiliki sumber daya manusia yang handal dan pakar dibidangnya khususnya bidang hukum dan hukum Islam, untuk memanfaatkan peluang dalam rangka penerapan hukum Islam di Indonesia. Kajian tentang hukum Islam tentunya diselaraskan dengan kajian yang bersifat kontemporer, kekinian dan keindonesiaan.

2. Hukum Islam yang bersumber dari al-Quran dan sunah, dan fikih diupayakan membumi. Dalam arti dapat mengimplementasikan dalam kehidupan masyarakat yang hidup di era globalisasi. Karena hukum Islam bersifat universal dalam segala bentuk permasalahan yang dihadapi masyarakat, sehingga hukum Islam dapat menjadi penawar dalam menyelesaikan problem masyarakat. Dalam pembentukan undang-undang atau aturan terkait lainnya, agar memperhatikan kondisi objektif masyarakat Indonesia, agar hukum Islam dapat dilaksanakan oleh masyarakat, dan upaya penerapan hukum Islam tidak mendapatkan tantangan dalam penerapannya. 


\section{DAFTAR PUSTAKA}

Al-Anshari, Mahmud, Penegakan Syari'at Islam: Dilema Keumatan di Indonesia. Cet. I; Jakarta: Inisiasi Press, 2005.

Ali, Mohammad Daud, Hukum Islam: Pengantar Ilmu Hukum dan Tata Hukum Islam di Indonesia. Jakarta: Raja Grafindo Persada, 2007.

Azizy, A. Qodri, Eklektisisme Hukum Nasional: Kompetisi Antara Hukum Islam dan Hukum Umum. Cet. 1; Yogyakarta: Gama Media, 2002.

Bisri, Cik Hasan, Kompilasi Hukum Islam dan Peradilan Agama dalam Sistem Hukum Nasional. Cet. II; Jakarta: Logos Wacana Ilmu, 1999.

Halim, Abdul, Politik Hukum Islam Di Indonesia. Cet. 1; Ciputat, Ciputat Press, 2005.

Ishak, Ajub "Pembentukan Hukum dan Tingkah Laku Sosial," Pemikiran Hukum dan Ekonomi Islam 6, no 1 (Juni 2010): h. 1-9.

Khaeruman, Badri, Hukum Islam dalam Perubahan Sosial. Cet. I; Bandung: Pustaka Setia, 2010.

Mu'allim, Amir, dan Yusdani, Konfigurasi Pemikiran Hukum Islam. Cet. 1; Yogyakarta: UII Press, 1999.

Mustofa dan Abdul Wahid, Hukum Islam Kontemporer. Cet. 1; Jakarta: Sinar Graft ka, 2009

Ranumulyo, Mohd. Idris, Asas-asas Hukum Islam: Sejarah Timbul dan Berkembangnya Kedudukan Hukum Islam dalam Sistem Hukum di Indonesia. Cet. 2; Sinar Grafika, 1997.

Rofiq, Ahmad, Hukum Islam Di Indonesia. Cet 4; Jakarta: Raja Grafindo Persada, 2000.

Pembaharuan Hukum Islam di Indonesia. Cet. 1; Yogyakarta: Gama Media, 2001.

Syarifuddin, Amir, Meretas Kebekuan Ijtihad: Isu-isu Penting hukum Islam Kontemporer di Indonesia. Cet. II; Ciputat: Ciputat Press, 2005.

Tebba, Sudirman, Sosiologi Hukum Islam. Cet. I; Yogyakarta: UII Press, 2003.

Usman, Suparman, Hukum Islam: Asas- asas dan Pengantar Studi Hukum Islam dalam Tata Hukum Indonesia. Cet. 2; Jakarta: Gama Media Pratama, 2002. 